\title{
Effect of retting methods on properties of Dhaincha fibres
}

\author{
MONIKA NEGI, ANITA RANI AND ANUPRIYA SINGH
}

Received: 28.04.2017; Revised: 29.09.2017; Accepted: 15.10.2017

See end of the paper for authors' affiliations

\section{ANUPRIYA SINGH}

Department of Clothing and Textiles, College of Home Science, G.B. Pant University of Agriculture and

Technology, Pantnagar, U.S. NAGAR (UTTARAKHAND) INDIA

Email : anupriya.singh2008@gmail. com
ABSTRACT : The dried ribbons of Sesbania aculeata (Dhaincha) plant were retted by chemical and biological retting methods. In first chemical retting method, the fibres were treated with the combination of EDTA and $\mathrm{NaOH}$ whereas in second method pretreated with $\mathrm{HCl}$ followed by $\mathrm{NaOH}$; In biological retting method both the stagnant and running water methods were utilized. The retted fibres were tested for physical properties such as, moisture content and weightloss. The percentage weight loss was found to be more in case of chemically retted fibres owing to the enhanced digestibility of lignocellulosic material by the alkali. Contrary to this, biological retting showed higher moisture content due to the presence of non cellulosic matter. Overall, the properties exhibited by Sesbania aculeata fibres obtained after 15 days of stagnant water retting was comparatively good as compared to other retting methods in terms of weight loss and moisture content.

KEY WORDS: Sesbania aculeata, Dhaincha, Fibre, Retting, Weight loss, Moisture content

- HOW TO CITE THIS PAPER : Negi, Monika, Rani, Anita and Singh, Anupriya (2017). Effect of retting methods on properties of Dhaincha fibres. Asian J. Home Sci., 12 (2) : 395-401, DOI: 10.15740/HAS/ AJHS/12.2/395-401. 